\title{
Financial crises, debt overhang, and firm growth in transition economies
}

\author{
Marco Botta ${ }^{\mathrm{a}} \mathrm{b}$ \\ aUniversità Cattolica del Sacro Cuore, Largo Gemelli 1, I-20123 Milano, Italy. \\ bUniversità degli Studi dell'Insubria, Via Sant'Abbondio 12, I-22100 Como, Italy.
}

\section{ARTICLE HISTORY}

Compiled February 3, 2020

\begin{abstract}
We examine the effects of the global financial crisis of 2008 and the European debt crisis of 2011 on the relationship between capital structure, investments, and performance for Eastern European companies. While the existing literature documents how firms' investments are sensitive to the availability of internal funds and to debt holdings, we further investigate whether this investment sensitivity also translates in different levels of performance, and document that capital structure indeed has both a direct and an indirect effect, mediated by the capital expenditure channel. We show that firms with higher financial flexibility experience higher investments and returns on capital. Over-levered firms instead suffer from a debt overhang condition, forcing them to curb investments, and consequently experiencing lower performance. Overall, we provide evidence on the importance of capital structure and financial flexibility on investments and performance, showing the real consequences of the debt overhang condition on firm value creation. Firms should therefore aim at maintaining adequate financial flexibility in order to be able to pursue future profitable investment opportunities, and avoid the under-investment problem arising from a debt overhang situation.
\end{abstract}

\section{KEYWORDS}

Capital structure; Debt overhang; Financial crises; Financial flexibility; Firm performance

JEL Classification: G01, G30, G32

CONTACT M. Botta. Email: marco.botta@unicatt.it 


\section{Introduction}

We study the potential effects of financing decisions on the performance of firms based in the transition economies of Eastern Europe, focusing in particular on the effects of excess leverage in times of global financial turbulence. Modigliani and Miller (1958) show that, under perfect capital markets, capital structure is irrelevant, and companies can undertake all value-generating investments regardless of how they decide to raise the required capital. As a consequence, the value of a firm does not depend on how it chooses to fund its operations. When imperfections are introduced in the model, though, capital structure may affect the investment decisions and the value of firms. As a result, firms may have an optimal level of leverage that maximizes their value by balancing costs and benefits of alternative financing decisions, like the tax-deductibility of interest payments (Modigliani and Miller (1963)), bankruptcy costs (Stiglitz (1969)), and agency costs (see, for example, Jensen and Meckling (1976), Myers (1977), and Jensen (1986)).

A smaller stream of literature has investigated what are the 'real' consequences of capital structure decisions, studying whether they produce effects on operating, rather than purely financial, outcomes. This line of research shows how, for example, financially flexible firms - defined as those with a debt ratio below its optimal level may have a greater ability to undertake investment opportunities (see, among others, Denis and Sibilkov (2010) and Duchin et al. (2010)), so that, under certain conditions, maintaining excess debt capacity may result in a value-enhancing strategy for a firm, despite the costs associated with lower-than-optimal leverage. Indeed, Graham and Harvey (2001) report that $59 \%$ of the CFOs they survey indicate financial flexibility as an important determinant of leverage levels, resulting in the single most commonly cited factor. Campello et al. (2010) survey 1,050 chief financial officers in various countries in December 2008 to gather direct information about the impact of financial constraints caused by the financial crisis (and the associated recession) of that year on corporate policies. They report that financially constrained firms planned to cut investments more, compared to financially unconstrained firms, and were forced to consume a relevant portion of their cash savings to support their activity. Moreover, 
nearly $90 \%$ of constrained companies said that financial constraints restricted their pursuit of attractive projects, and more than half of them were forced to cancel valuable investments. All these findings suggest that firms that were over-levered before the beginning of the financial crisis are likely to have suffered from lower investments in the subsequent years. However, it doesn't provide evidence on the overall effects on the subsequent performance of companies.

Building on the existing evidence on the importance of financial flexibility, Almeida et al. (2011) develop an inter-temporal model of leverage decisions to account for the effects of current decisions on future costs of raising capital. Their model shows how current high leverage may have a significant impact on future financing costs, and, through this, distort real investments away from their optimal levels. The expected reduction in value due to distorted investments might explain why firms set their debt ratio lower than the supposedly optimal target derived from traditional tradeoff models. Future financial flexibility is therefore a key variable to account for when setting a firm's leverage ratio. On the contrary, having too much debt would put firms in a 'debt overhang' condition, so that they give up otherwise profitable investment opportunities because their capital structure doesn't allow them to raise the required capital, or would allow them to do so only at significant costs.

We focus on this potential source of frictions, and empirically investigate the effects of capital structure decisions of listed firms located in the transition economies of Eastern Europe on their ability to pursue investment opportunities and create value during the Global Financial Crisis (GFC) and the European Debt Crisis (EDC). Indeed, both the GFC and the EDC caused a negative shock to capital supply, hence providing an interesting environment for testing the effect of alternative financing strategies on the value creation of firms. We contribute to the existing literature by focusing on the effects in times of financial crises of excessive debt on corporate investments and on firms' performance, both directly and indirectly through the capital expenditure channel. In addition, by focusing on firms that are not incorporated in one of the economies where the GFC and the EDC originated, we provide firm-level evidence on the effects that these two events have produced also on firms based in other countries, contributing to the literature on economic and financial integration. 
More specifically, the aim of this work is to understand whether maintaining financial flexibility is a value enhancing strategy, and what are its effects on firms' investment decisions. To this end, we first identify financially flexible firms by estimating a leverage equation from which we can determine a firm-specific optimal level of debt. We then define financial flexibility, an unobservable characteristic, as the deviation of observed leverage from the estimated optimal value. Finally, we estimate whether this wedge between actual and optimal leverage produces any effect on the level of investments and on performance. If firms are able to properly identify future growth opportunities, they may decide to maintain spare debt capacity to be able to quickly raise new external capital when they need to undertake new investments. If this hypothesis hold, then we should observe a positive impact of financial flexibility on investments and, through this channel, on future performance. However, too little leverage may also damage a firm's performance, as shown by Jensen (1986), because managers use available funds to pursue private perks, rather than efficient investment policies. If this is true, we would then obtain that financially flexible firms invest more, but these higher investments translate into a decrease in performance, because of inefficient investment decisions.

Through this analysis, we find that companies in the transition economies of Eastern Europe were deeply affected by the financial turmoil that originated in 2008 in the US and, later in 2011, in Western Europe. We provide evidence on the validity of the debt overhang hypothesis: over-levered firms experience a negative effect on their ability to pursue optimal levels of investment and, ultimately, to produce higher returns to investors. Firms that entered the global financial crisis of 2008 with lower-than-optimal leverage experienced higher cumulative profits in the following decade. We also report a strong and significant debt sensitivity of investments, producing an indirect and significant effect on performance. Our findings therefore show how companies that are able to maintain financial flexibility in the form of spare debt capacity are not only able to invest more, but also seem to take more profitable investment decisions. The fact that firms accumulate financial resources in the form of spare debt capacity does not therefore translate in an inefficient use of capital. This indicates that the potential agency issues connected with lower-than-optimal leverage are more than compensated 
by the increased ability to pursue profitable growth opportunities, limiting the debt overhang issue. Firms may therefore rationally decide to maintain sub-optimal levels of leverage in order to avoid incurring in financial constraints that would force them to pass up profitable investment opportunities.

While there is ample work on the determinants of capital structure, on the analysis of investment decisions, and on the debt or cash holdings sensitivity of investments, there is little work on the complex link between financial decisions, investments, and the operating performance of firms. Through our analysis, we contribute to expanding our understanding on the link between financial and investment decisions, and their effects on the operating performance of firms. Overall, our findings provide evidence against the irrelevance of capital structure, on the value of financial flexibility, and on the consequences of the debt overhang condition on firm value creation.

The article is organized as follows: Section 2 reviews the pertinent literature and presents the research hypotheses that we intend to investigate. Section 3 illustrates the methodology adopted for our investigation, while Section 4 describes the dataset used. Section 5 discusses our findings, and Section 6 concludes.

\section{Literature review and research hypotheses}

In a friction-less world, Modigliani and Miller (1958) show that firms' financial structure is irrelevant for their investment decisions because external funds can always be raised at no cost when internal funds are not sufficient. However, imperfections in the real world do not allow firms to obtain new capital without incurring in additional costs, and, as a consequence, internal and external funds are not perfect substitutes (Fazzari et al. (1988)).

A significant stream of literature has therefore investigated the effects of financial constraints and changes in capital supply on the ability of firms to pursue new investment opportunities (Hoshi et al. (1991); Kaplan and Zingales 1997); Arslan et al. (2006); Aggarwal and Zong (2006); Lemmon and Roberts (2010); Ahiadorme et al. (2018)). All these works highlight how firms are forced to curb investments when internal funds are not sufficient and they are facing constraints on their ability to raise 
new capital, either because of external shocks to capital supply or because of firm-level conditions that dissuade investors from providing the requested funds. As a result, financially constrained firms may under-perform their peers due to a systematic lower level of investment caused by their inability to raise the required capital. Indeed, Botta (2019a) shows how, in a sample of small and medium-sized firms operating in the hotel industry, failing to adopt an optimal capital structure produces a lower financial performance.

More recently, some authors have begun to investigate the real effects of the GFC on the corporate sector looking at the impact on firms' investments, as the GFC itself provides for an extraordinary negative shock in capital supply that may have significantly affected corporate behaviors. In particular, Duchin et al. (2010) show how corporate investments declined significantly for US firms at the outburst of the global financial crisis, with a stronger reduction for firms with low cash reserves or high short-term debt, a result consistent with the hypothesis that shocks to capital supply may affect investment decisions. Their findings suggest that firms face a relevant motive for accumulating precautionary savings, or maintaining excess debt capacity, in order to support their investment strategies even under negative market conditions, an effect that is often neglected in the literature, both theoretical and empirical.

Similarly, Arslan-Ayaydin et al. (2014) analyze the effect of the Asian 1997-1998 crisis and the 2007-2009 credit crisis on the investments of East Asian firms. They report that firms with higher financial flexibility before the Asian crisis experienced a greater ability to take investment opportunities, and had to rely much less on the availability of internal funds to invest. They also report that similar effects can be observed following the GFC, but in a much weaker form, suggesting that local crises may have a larger impact than international ones, at least in emerging economies. They also find that the value of financial flexibility is country-specific, because of differences either in national institutions or in financial conditions (like currency regimes, exchange rate risk, monetary policy). Francis et al. (2013) report similar findings on the interconnection between firms' financial constraints and national institutions in a sample of companies from fourteen different emerging market countries. They report that better corporate governance lowers the dependence of emerging market firms on 
internally generated funds, and reduces financing constraints that would otherwise distort investment decisions. They also find that firm-level corporate governance matters more significantly in countries with weaker country-level governance, suggesting some form of substitution effect between firm-specific and country-level governance.

Balfoussia and Gibson (2019) investigate whether the sensitivity of firm-level investment to cash flow for companies within the Euro Area is time-varying, focusing in particular on changes in market-wide financial conditions. Looking at the effect of the GFC on corporate behavior, they report that financial conditions have indeed played a significant role in corporate investment decisions, especially for financially constrained firms.

Finally, Casey and O'Toole (2014) focus instead on the behavior of European small and medium-sized enterprises (SMEs) during the GFC. They report how creditrationed firms were more likely to rely on trade credit, and also more likely to use informal lending or loans from other companies. They also find no evidence that bankconstrained SMEs resorted to market finance to raise new capital. In particular, they find that firms denied credit for working capital turned to trade credit, while informal and inter-company lending acted as a substitute for bank loans aimed at funding new investments.

These findings are consistent with results concerning the role of macroeconomic conditions and national institutions on cash holdings management (Demir and Er$\operatorname{san}(2017)$; Orlova and Sun (2018)), capital structure decisions (Korajczyk and Levy (2003); Cook and Tang (2010); Gungoraydinoglu and Öztekin (2011); Öztekin and Flannery (2012); Belkhir et al. (2016); Alcock and Steiner (2017); Botta and Colombo (2017); Çolak et al. (2018)), the cost of issuing equity (Guyot et al. (2014); Botta (2019b)), and the cost of borrowing new funds (Krivogorsky et al. (2018)).

All these factors may indeed contribute to explain why financially constrained firms may suffer an under-investment problem, and particularly so during a financial crisis. If raising new capital is costly, and more so during a financial crisis, then firms with insufficient internal funds may give up profitable investment opportunities because the costs they would incur in raising the required capital, and especially additional equity, are greater then the net present value of the potential new investment. As a result, 
past financing decisions, by affecting the availability of internal funds and spare debt capacity, may affect future investment decisions and a firm's ability to support growth and returns to investors.

We build on this literature and analyze whether, during both the GFC and the EDC, past financing decisions affected firms' ability to generate new value for their investors. This may be a consequence of under-investments by capital-constrained firms (Myers (1977)) that obstacles the pursuit of an efficient investment plan and ends up reducing the operating performance. In addition, firms may suffer from a decline in sales or an increase in costs because of the indirect costs of financial distress Opler and Titman (1994)), hence suffering again a lower performance because of their excessive debt. However, firms may also benefit from moderate amounts of debt, because it reduces the amount of cash flow under the control of managers, who may otherwise destroy value by investing internal funds to pursue private perks rather than valueincreasing projects (Jensen (1986)). While the literature, as described above, has often investigated whether financial conditions affect the level of investments, there is little evidence concerning the implications on the overall performance of firms.

We hypothesize that, in line with the literature, over-indebted firms suffer from a severe debt overhang condition during a financial crisis, and are forced to reduce their investments due to the difficulties and the costs of raising additional capital. In turn, this reduction in investments affects their operating performance in the subsequent periods, so that excessive leverage produces an indirect effect on future performance, through the capital expenditure channel.

Focusing on Eastern European countries allows us to evaluate the effects of the GFC and the EDC in transition economies that are becoming more and more integrated with the advanced western economies. In fact, on the one hand, Nivorozhkin (2005) shows that firms in the transition economies of Eastern Europe have similar debt ratios to their competitors in Western European countries. They also display a similar speed of adjustment of their capital structure, and the factors that affect the target debt ratios of firms in Western Europe are also valid determinants for their counterparts in Eastern Europe. On the other hand, Muradoğlu et al. (2014) shows the importance of capital supply factors on firms' financing choices, by showing that firms increase 
equity financing when their country of residence joins the EU (thus allowing for an higher integration of the local equity market ${ }^{1}$ ), while they increase debt financing (as well as both short and long-term borrowing) when their country adopts the Euro, an event likely to improve the credit channel. By analyzing firms incorporated in Eastern Europe, we are able to investigate if and how the financial turbulence generated in the US, during the global financial crisis, and in western Europe, during the European debt crisis, has propagated to the companies of countries that had only recently joined the European Union and, in some cases, the Euro, thus contributing to the firm-level literature on economic and financial integration.

\section{Methodology}

\subsection{Analysis of corporate investments}

We investigate the determinants of firms' investments (capital expenditure, or $C E$ ) as a function of the difference between the effective debt ratio of the company and its estimated optimal level, that we define excess debt2. We also include a set of firm characteristics as control variables, in an augmented version of a classic investment model (see, among others, Fazzari et al. (1988), or Arslan et al. (2006)).

In order to control for potential endogeneity in the investment equation, and to account for persistence in the level of investments, we use the dynamic panel systemGMM estimator proposed by Blundell and Bond (1998). This method allows us to accurately account for persistence and endogeneity, and to properly treat the relatively small sample size with respect to the time dimension. To this ends, the dynamic

\footnotetext{
${ }^{1}$ Bekaert et al. (2013) show that equity market integration in Europe was achieved mainly during the accession phase to the EU, while the launch of the European Monetary Union (EMU) and the adoption of the Euro had a non-significant impact. In order to join the EU, Eastern European countries had to sign the Maastricht Treaty, which prescribes the free movement of goods, capital, people and services between EU members. Moreover, they had to implement in their national laws the prescriptions of the EU directives, including those aimed at harmonizing the regulation of capital markets and financial services. As a consequence, joining the EU implied that foreign investors had free access to equity markets, and that regulation was in the same line as that of advanced European economies, resulting in effective protection of transparency and property rights. In the end, this allowed for an increase in the supply of equity capital for domestic firms.

${ }^{2}$ See Appendix A for a thorough description of how we estimate a firm-specific measure of excess debt.
} 
panel system-GMM method jointly estimates a regression of the relevant equation in differences together with the regression in levels (hence why it is called a systemGMM estimator), using lagged levels as instruments for the regression in differences and lagged differences as instruments for the regression in levels.

In order to provide valid results, the system-GMM estimator requires that differences of the right-hand side variables must not be correlated with the firm-specific effect. To assess the validity of our instruments we perform an m2 test for secondorder autocorrelation in the first-differenced residuals, as well as the Hansen J-test of over-identifying restrictions. Both tests indicate that the model chosen and the set of instruments used are appropriate.

Equation (1) defines our regression model:

$$
\begin{aligned}
C E_{i, t}= & \alpha+\rho * C E_{i, t-1}+\beta_{1} * \text { excess debt } t_{i, t-1} * N E D_{i, t-1}+ \\
& +\beta_{2} * \text { excess debt } t_{i, t-1} * E D_{i, t-1}+\gamma X_{i, t-1}+u_{i}+\epsilon_{i, t}
\end{aligned}
$$

where $i$ indicates firm, and $t$ indicates time, $E D$ is a dummy equal to one if the firm is above target leverage in the corresponding year, $N E D$ is a dummy equal to one if the firm is instead below target leverage in the corresponding year, excess debt is the difference between observed leverage and the estimated target leverage, $u_{i}$ indicates firm fixed effects, $\alpha, \beta$, and $\rho$ are parameters, and $\epsilon$ is the error term.

The set of control variables includes firm characteristics that are likely to affect firms' investment decisions, in line with the previous literature $3^{3}$. First, we control for investment opportunities by means of two classic determinants of capital expenditure: the variable growth, as a proxy for Tobin's Q and measured as the ratio between the total market capitalization and the book value of equity, and profit, defined as the ratio between operating cash flow and total assets, and measuring the ability of a firm to generate new funds from its operating activity. Then, we include size, measured as the natural logarithm of firm sales, corrected for inflation as a proxy for the maturity of a firm, and tangible, defined as the ratio of fixed tangible assets to total assets, and

\footnotetext{
${ }^{3}$ See, among others, Hubbard (1998); Malmendier and Tate (2005); McNichols and Stubben $\sqrt{2008)}$; GarcíaSánchez and García-Meca (2018).

${ }^{4}$ We deflate nominal values using 2010 as the base year.
} 
intangible, defined as the ratio of fixed intangible assets to total assets to account for the investments required for maintaining the efficiency of fixed assets already in place. Finally, we include a set of variables to account for additional financial factors, like the availability of internal funds (cash), defined as the sum of cash and equivalents divided by total assets, the net working capital ratio $(W C)$ to correct for the risk connected with operating payables and receivables, and the Ohlson's O-score (Ohlson) to consider the overall risk of default given the financial and operating assets and liabilities of the firm 5

It is worth noting that the analysis may suffer from a very specific endogeneity issue for which we need to control appropriately. Firms may have low growth opportunities, and therefore decide to increase their leverage ratio to control agency problems, and, simultaneously, because of the low growth opportunities, invest less. This may produce a negative relationship between leverage and investment that is not an indication of higher debt hampering the ability to invest, but rather that firms with lower growth opportunities invest less and at the same time use high levels of debt to control managerial efficiency. In order to control for this potential reverse causality, we include an estimate of growth opportunities both in the target leverage equation and in the investment equation. This way, our results explicitly incorporate the effects of growth opportunities on the decisions concerning both the optimal level of debt and the optimal level of investments. Therefore, our findings are net of the effect that might be due to this reverse causality of growth opportunities on investments and debt decisions.

\subsection{Analysis of value creation}

In a second step, we then investigate firms' ability to produce value for investors by means of the Return on Assets $(R O A)^{6}$. We define $R O A$ as earnings before interest and taxes $(E B I T)$ divided by total assets. The advantage of this metric is that it is easily understood, it can be calculated from available data, and it can be decomposed in different components to highlight how different aspects of managing a company affect the overall ability in creating new value. Moreover, its value is independent on capi-

\footnotetext{
${ }^{5}$ For a thorough description of how the index is calculated, see Ohlson 1980 .

${ }^{6}$ See, among others, Ramezani et al. (2002) for a discussion on how to measure firm value creation.
} 
tal structure, hence making its value directly comparable among firms with different leverage policies? We concentrate our attention in particular on two components of $R O A$. First, we analyze the return on sales $(R O S)$, obtained as the ratio between EBIT and net sales, that measures the operating efficiency of a firm by indicating the margin produced for each unit of sales. Then, we analyze the asset turnover (Turnover), obtained as the ratio between net sales and total assets, that indicates the ability of a firm in deploying its assets to generate revenues. In other words, it summarizes the amount of revenues that a firm is able to generate per unit of assets in place, and it measures the effectiveness of a firm in the use of its assets.

Given our focus on the role of financing decisions on firms' performance, we analyze ROA (and its two components) by including excess debt as a direct potential determinant. More specifically, as for the analysis of capital expenditure, we include the variable excess debt interacted with both the dummy $E D$ and the dummy $N E D$ in order to allow for different effects of increases in leverage between under-levered and over-levered firms. We then explore the potential indirect effect of capital structure on future returns, through its effect on firms' investments (the 'capital expenditure channel'). To this end, we include the variable capex, in order to both test whether higher investments are associated with higher performance and, depending on the results of the analysis of the debt-capital expenditure relation, also to assess the potential existence of an indirect effect of capital structure. Further regressors (already described in the previous section) are then added to the analysis as additional controls, in order to better isolate and identify the effect of capital structure on performance. As before, we rely on the dynamic panel system-GMM estimator proposed by Blundell and Bond $(1998)$ in order to account for both potential endogeneity and serial correlation in the dependent variables ROA, ROS, and Turnover. Again, following our estimation we perform all the tests that are necessary to ensure that the model is properly specified and that we use a valid set of instruments in order to obtain robust results.

\footnotetext{
${ }^{7}$ On the contrary, the most common alternative metric, the return on equity (or $R O E$ ), depends crucially on financing decisions, since it measures the returns produced for shareholders only. Therefore, two companies with the same operating performance but a different capital structure would produce different values of $R O E$. In our analysis, we want to test whether leverage policies affect operating performance, and therefore we need a performance metric that, in its calculation, is independent of capital structure.
} 


\section{Dataset}

Our dataset includes yearly observations for firms listed in any of the following Eastern European countries that are currently members of the European Union: Bulgaria, Croatia, Czech Republic, Estonia, Hungary, Latvia, Lithuania, Poland, Romania, Slovakia, and Slovenia. Data are collected for the period that goes from 2004 until 2017. Selecting countries that belong to the European Union ensures that the companies in the sample operate in a regulatory framework that is homogeneous, due to the harmonization process required for accessing the European Union itself. Finally, we require firms to have at least three consecutive years of data in order to be included in our sample. The resulting sample comprises a total of 18.536 firm-year observations. We retrieve all accounting data from Worldscope, while market and macroeconomic data are from Datastream.

Table 1 summarizes the distribution of firms in the sample across time and countries.

[Table 1 about here.]

In line with the capital structure literature, the sample does not include financial and utility companies, because their financing decisions are severely affected by industryspecific regulations, which would make them hardly comparable with companies in other sectors. Firms are sorted within industries based on the four-digit code assigned by Worldscope.

\section{Results}

\subsection{Capital structure and investments}

The capital structure literature hints at the possibility that over-indebted firms with low internal funds may have experienced a decrease in investments during both the GFC and the EDC, because their debt capacity was exhausted and they were reluctant at issuing new equity, consistently with the results in Kahle and Stulz (2013), either because it would have been too costly or because investors were not willing to take up new equity issues in a period of high uncertainty and increased risk aversion (Dissanaike et al. (2014)). 
We therefore begin our empirical analysis by investigating the relationship between firm investments and their capital structure. We focus, in particular, on the effect on capital expenditure of the deviation of the observed leverage from the estimated optimal level, as described in Section 3, to examine whether excessive leverage produces any effect on the level of investments. Table 2 reports the results.

[Table 2 about here.]

When looking at the entire sample period, we find a negative effect of excess debt on capital expenditure. When a firm increases leverage above its optimal level, capital expenditure decreases, as indicated by the negative and statistically significant coefficient for excess $d e b t^{*} E D$. There is instead no effect if leverage increases but remains below its optimal level, as indicated by the coefficient for excess $d e b t^{*} N E D$, showing the existence of a kink in the debt-capital expenditure relation 8 , The coefficient for the lagged dependent variable is significant and ranging between $19 \%$ and $26 \%$, a sign that the persistence of firm investments over time is relatively moderate.

These findings are confirmed when looking at the two sub-periods (the GFC and the EDC, respectively). It is interesting to note how this effect has become stronger during the EDC, suggesting that the debt overhang issue has become more binding during that period. We obtain similar results when focusing on the Ohlson's O-score (Ohlson): firms with higher financial risk (i.e. a higher value of the score) invest less, another sign of the existence of financial constraints.

We also find that the cash ratio (cash) has a positive effect on capital expenditure, and this effect is stronger during the GFC than in the EDC or the entire sample. The sensitivity of corporate investments to excessive debt usage is therefore significant, and becomes stronger during periods of financial turbulence, providing evidence in favour of the debt overhang hypothesis.

Our findings also suggest that firms incorporated in countries belonging to the Euro area did not display a higher or lower level of investments than those in other countries.

\footnotetext{
${ }^{8}$ Note that $N E D$ is a dummy variable equal to one if excess debt is negative. Recall also that excess debt is negative when a firm's leverage is below the target, so that in this case an increase in excess debt indicates that a firm is moving closer to the target. As a consequence, a positive coefficient, if statistically significant, would imply a positive effect of leverage increases.
} 
Indeed, while the coefficient for Euro is statistically significant in the full sample and in the EDC sub-sample, its magnitude indicates that the economic impact was negligible.

\subsection{Capital structure, investments and profits}

In this second step, we investigate whether the effect of capital structure on investments translates into a lower ability of firms to create value for their investors. Table 3 summarizes our findings.

[Table 3 about here.]

The first thing to notice is that the degree of persistence for $R O A$ and $R O S$ is relatively low. Except for the GFC period, it is instead quite strong for the asset turnover ratio.

Then, starting with the analysis of overall performance (measured by $R O A$ ) over the full sample period, we find a negative effect of excessive debt. Moreover, we find a positive effect of capex, indicating that firms that invest more experience higher returns on their assets. Given the negative effect of excess debt on investments reported before, this also implies a negative indirect effect of debt on profits: due to the debt overhang issue, over-levered firms invest less. These lower investments, in turn, produce a negative effect on firm performance. This is highlighted also by the analysis of asset turnover: by investing less, firms experience a reduced ability to deploy their assets to generate revenues, possibly because their assets in place become obsolete. We also find a negative effect of excess debt on the asset turnover, while we do not detect any effect of leverage on operating efficiency, neither direct nor indirect: $R O S$ is not significantly affected by leverage, nor by capital expenditure. Next, we repeat the analysis for the GFC sub-period. Here, we also find a direct effect of excessive leverage on performance and on asset turnover, as well as an indirect effect through the capital expenditure channel. In fact, the overall effect of leverage on performance appears even stronger in this sub-period. In the EDC sub-period, we again find evidence of both a direct and an indirect effect of leverage on ROA, through the capital expenditure channel and the asset turnover channel, which in turn is directly and negatively affected by excess debt. In this case, however, the indirect effect of leverage on performance appears stronger 
than the direct one. This is also because, in this sub-period, ROS is positively affected by higher capital expenditure, which is also negatively affected by excess debt. In turn, ROS has a positive effect on ROA, so again there is an indirect effect of leverage on performance.

Overall, the analysis suggests the existence of a complex mechanism through which the debt overhang issue has affected firm performance during the two financial crises. In particular, during the GFC there is a strong direct effect of capital structure on firm performance, while the indirect effect through the capital expenditure channel appears as a second-order factor. The opposite happens during the EDC, where we detect indirect effects of excess debt on performance which are stronger than the direct effect. This may depend on the fact that, initially, over-levered firms were perceived as more risky, therefore losing market power in favour of more solid competitors; the lower investments due to the debt overhang issue, instead, were not yet producing negative effects on their profits. The EDC that followed made the financial turbulence particularly long for European companies, exacerbating the under-investment issue for over-levered firms, so that with time their systematically lower capital expenditure produced effects on their profits. In fact, over-levered firms reported both a lower asset turnover and a lower ROS, a sign that, by investing less, they were becoming less capable of extracting value from assets in place, and their operating efficiency was also deteriorating.

To further investigate the relationship between differences in capital structure and subsequent profits, we analyze the cumulative performance of companies from the beginning of the crisis (2008) until the end of our sample period (2017) as a function of excess debt observed in the final year before the financial crisis. In other words, we analyze whether the situation of firms' capital structure at the beginning of the financial crisis has produced significant effects on their overall performance in the subsequent years of economic turmoil. Table 4 reports our findings.

[Table 4 about here.]

Columns (1) and (2) refer to ordinary least squares regressions, and indicate that firms below the target debt ratio experienced an higher performance following the 
GFC than those which were closer to the target itself, as indicated by the coefficient for Excess debt*NED. Moreover, when also including the Ohlson's O-score measured before the crisis as determinant, we also find that more over-levered firms performed worse, as indicated by the negative coefficient for Excess debt*ED. The coefficient for Ohlson also suggests that more indebted firms reported a lower profitability in the aftermath of the GFC and the EDC. Columns (3) and (4) report the results for interquartile regressions, using the same set of dependent and independent variables, comparing the $80^{\text {th }}$ with the $20^{\text {th }}$ percentile of the dependent variable ROA. In this case, we find that differences in the cumulated ROA are mainly due to the ability of firms to deploy their assets to generate revenues (Asset turnover) and by being below the target debt ratio (Excess debt*NED), while the other variables do not seem to produce a significant effect on the dispersion of the measured performance. Overall, these findings support our previous results and provide further evidence that Eastern European firms suffered from a debt overhang problem during the global financial crisis and the European debt crisis.

\section{Conclusions}

The role of capital structure decisions within a firm represents a long standing debate in corporate finance. We expand this literature by examining the real effect of different leverage policies on firms' investments and performance, focusing on the transition economies of Eastern Europe that have joined the European Union. In particular, we examine whether different capital structure decisions have affected firms' outcomes following the financial turbulence that generated outside the examined set of countries, namely the Global Financial Crisis that started in the US in late 2008, and the European Debt Crisis that began in Western Europe in 2011. This also allows us to see the effects that external events produce on companies based in economies that have been recently integrated in the global economy. In particular, our purpose is to verify whether the firms examined suffered from a debt overhang issue, so that those with excess leverage had to reduce investments during the crises due to financial constraint, and, consequently, experienced lower profitability. If this is true, then failing to adopt 
an optimal capital structure may directly or indirectly cause a decrease in the ability to produce returns for investors, hence affecting the value of companies.

We find that during both crises capital structure produces a significant real effect on the firms in our sample, so that those with an higher-than-optimal level of leverage report a reduction in capital expenditure and in returns produced. Leverage has both a direct effect on performance, and an indirect effect through the capital expenditure channel: over-levered firms invest less, and lower investments in turn produce lower future profits. More specifically, when examining the determinants of capital expenditure we find that increasing leverage while being already above the target produces a reduction in investments, whereas no significant relationship emerges for under-levered firms. Corporate investments display a significant sensitivity to excessive debt usage, an effect that becomes even stronger during both the GFC and the EDC, providing supporting evidence to the debt overhang hypothesis, and showing its severity during periods of financial turbulence.

When we investigate the overall effects of capital structure, both direct and indirect, on firm value creation, the analysis suggests the existence of a complex mechanism through which the debt overhang issue affects firm performance. When examining the entire sample period, we find evidence of both a direct and an indirect effect of leverage on performance. The transmission channels are however different during the two financial crises. In particular, during the GFC there is a direct effect of capital structure on firm performance, while no indirect effect through the capital expenditure channel. The opposite happens during the EDC, where we detect indirect effects of excess debt on performance, but no direct effect.

This may indicate that, initially, over-levered firms were perceived as more risky, therefore losing market power in favour of more solid competitors; this confirms the results in Love and Zaidi (2010), who suggest that liquidity shocks may produce significant effects along the supply chain. On the other hand, capital expenditure may affect performance only in the long run, so that the lower investments due to the debt overhang issue were not yet producing negative effects on profits at the beginning of the crisis. The EDC that followed made the financial turbulence particularly long for European companies, exacerbating the under-investment issue for over-levered firms, 
so that with time their systematically lower capital expenditure ended up affecting their ability to produce higher profits. In fact, over-levered firms reported both a lower asset turnover and a lower ROS (through the capital expenditure channel), a sign that, by investing less, they were becoming less capable of extracting value from assets in place, and their operating efficiency was also deteriorating.

Overall, our findings indicate that companies in transition economies were deeply affected by financial events that had their origin in developed Western economies. In particular, over-levered firms suffered from a debt overhang issue, so that their inefficient capital structure affected their ability to pursue optimal levels of investment and, ultimately, produce higher returns to investors. Indeed, our results indicate that firms that were under-levered in 2008 experienced higher cumulative profits in the following decade. Leverage and the ability to use assets to produce revenues are the two main factors that contribute at explaining differences in performance, showing that there is a strong and significant debt sensitivity of investments that produces an effect on performance. In the end, this suggests that capital structure is far from being irrelevant, and firms may actually decide to maintain excess debt capacity, in the form of lower-than-optimal leverage, to avoid financing constraints caused by negative external events.

These findings provide interesting insights to policymakers and capital market regulators. If financial flexibility plays such an important role in firms' performance, then national decision-makers should focus on implementing policies that aim at ensuring that growth is not limited by financing constraints at the firm level.

In this respect, there are several areas of potential policy intervention. First of all, authorities should focus on ensuring that credit (and equity) markets operate properly, especially in periods of financial tensions, in terms both of liquidity and of transparency.

In addition, they should establish a legal system that facilitates the restructuring of private-sector debts through the optimal design of bankruptcy procedures and the efficient operation of the courts system. To this end, default procedures and regulation in general should guarantee that firms can quickly restore debt capacity by efficiently re-balancing their capital structure, so that they should not be forced to pass up prof- 
itable investment opportunities simply because they are not able to raise the required external capital. Among other things, regulation should offer adequate recognition and validity to of out-of-court settlements, so that lenders and borrowers can quickly and credibly restructure a firm's liabilities, without fearing to incur in penalties in the event of a subsequent bankruptcy.

Another important factor for a successful resolution of a debt overhang condition is the health of the banking sector. A key factor for implementing restructuring policy is the ability of banks to recognize losses, and this implies that they must be well capitalized to avoid that a financial shock transforms into a credit shock that significantly constrain firms' investment behavior.

Further research may complement this work and try to identify what are the legislative or cultural factors at the country level, if any, that may contribute at explaining why financial flexibility plays such an important role in the countries investigated.

\section{References}

Aggarwal, R., Zong, S., 2006. The cash flow-investment relationship: International evidence of limited access to external finance. Journal of Multinational Financial Management 16, 89-104.

Ahiadorme, J.W., Gyeke-Dako, A., Abor, J.Y., 2018. Debt holdings and investment cash flow sensitivity of listed firms. International Journal of Emerging Markets 13, 943-958.

Al-Najjar, B., 2011. Empirical Modelling of Capital Structure. Journal of Emerging Market Finance 10, 1-19.

Alcock, J., Steiner, E., 2017. Unexpected Inflation, Capital Structure, and Real Riskadjusted Firm Performance. Abacus 53, 273-298.

Almeida, H., Campello, M., Weisbach, M.S., 2011. Corporate financial and investment policies when future financing is not frictionless. Journal of Corporate Finance 17, 675-693. arXiv:arXiv:1011.1669v3.

Arslan, Ö., Florackis, C., Ozkan, A., 2006. The role of cash holdings in reducing investment-cash flow sensitivity: Evidence from a financial crisis period in an 
emerging market. Emerging Markets Review 7, 320-338.

Arslan-Ayaydin, Ö., Florackis, C., Ozkan, A., 2014. Financial flexibility, corporate investment and performance: evidence from financial crises. Review of Quantitative Finance and Accounting 42, 211-250.

Balfoussia, H., Gibson, H.D., 2019. Firm investment and financial conditions in the euro area: evidence from firm-level data. Applied Economics Letters 26, 104-110.

Bekaert, G., Harvey, C.R., Lundblad, C.T., Siegel, S., 2013. The European Union, the Euro, and equity market integration. Journal of Financial Economics 109, 583-603.

Belkhir, M., Maghyereh, A., Awartani, B., 2016. Institutions and corporate capital structure in the MENA region. Emerging Markets Review 26, 99-129.

Blundell, R., Bond, S., 1998. Initial Conditions and Moment Restrictions in Dynamic Panel Data Models. Journal of Econometrics 87, 115-143.

Botta, M., 2019a. Financing Decisions and Performance of Italian SMEs in the Hotel Industry. Cornell Hospitality Quarterly 60, 335-354.

Botta, M., 2019b. First-move advantage in seasoned equity offerings: evidence from European banks. Global Finance Journal 41, 1-12.

Botta, M., Colombo, L.V.A., 2017. Macroeconomic conditions, institutions, and nonlinear debt dynamics. Working paper - PFMC 2017 - Paris Financial Management Conference .

Campello, M., Graham, J.R., Harvey, C.R., 2010. The real effects of financial constraints: Evidence from a financial crisis. Journal of Financial Economics 97, $470-487$.

Casey, E., O'Toole, C.M., 2014. Bank lending constraints, trade credit and alternative financing during the financial crisis: Evidence from European SMEs. Journal of Corporate Finance 27, 173-193.

Çolak, G., Gungoraydinoglu, A., Öztekin, Ö., 2018. Global leverage adjustments, uncertainty, and country institutional strength. Journal of Financial Intermediation $35,41-56$.

Cook, D.O., Tang, T., 2010. Macroeconomic Conditions and Capital Structure Adjustment Speed. Journal of Corporate Finance 16, 73-87. 
Demir, E., Ersan, O., 2017. Economic policy uncertainty and cash holdings: Evidence from BRIC countries. Emerging Markets Review 33, 189-200.

Denis, D.J., Sibilkov, V., 2010. Financial Constraints, Investment, and the Value of Cash Holdings. Review of Financial Studies 23, 247-269.

Dissanaike, G., Faasse, J., Jayasekera, R., 2014. What do equity issuances signal? A study of equity issuances in the UK before and during the financial crisis. Journal of International Money and Finance 49, 358-385.

Duchin, R., Ozbas, O., Sensoy, B.A., 2010. Costly external finance, corporate investment, and the subprime mortgage credit crisis. Journal of Financial Economics 97, 418-435.

Elsas, R., Florysiak, D., 2011. Heterogeneity in the Speed of Adjustment toward Target Leverage. International Review of Finance 11, 181-211.

Fazzari, S.M., Hubbard, R.G., Petersen, B.C., Blinder, A.S., Poterba, J.M., 1988. Financing Constraints and Corporate Investment. Brookings Papers on Economic Activity 1988, 141. arXiv:arXiv:1011.1669v3.

Flannery, M.J., Rangan, K.P., 2006. Partial Adjustment Toward Target Capital Structures. Journal of Financial Economics 79, 469-506.

Francis, B., Hasan, I., Song, L., Waisman, M., 2013. Corporate governance and investment-cash flow sensitivity: Evidence from emerging markets. Emerging Markets Review 15, 57-71.

Frank, M.Z., Goyal, V.K., 2009. Capital Structure Decisions: Which Factors Are Reliably Important? Financial Management 38, 1-37.

García-Sánchez, I.M., García-Meca, E., 2018. Do talented managers invest more efficiently? The moderating role of corporate governance mechanisms. Corporate Governance: An International Review 26, 238-254.

Graham, J.R., Harvey, C.R., 2001. The theory and practice of corporate finance: evidence from the field. Journal of Financial Economics 60, 187-243.

Graham, S.J.H., Marco, A.C., Myers, A.F., 2018. Monetizing marks: insights from the USPTO Trademark Assignment Dataset. Journal of Economics \& Management Strategy 27, 403-432.

Gungoraydinoglu, A., Öztekin, Ö., 2011. Firm- and Country-Level Determinants of 
Corporate Leverage: Some New International Evidence. Journal of Corporate Finance 17, 1457-1474.

Guyot, A., Lagoarde-Segot, T., Neaime, S., 2014. Foreign shocks and international cost of equity destabilization. Evidence from the MENA region. Emerging Markets Review 18, 101-122.

Hoshi, T., Kashyap, A., Scharfstein, D., 1991. Corporate Structure, Liquidity, and Investment: Evidence from Japanese Industrial Groups. The Quarterly Journal of Economics 106, 33-60.

Hovakimian, A., Li, G., 2011. In Search of Conclusive Evidence: How to Test for Adjustment to Target Capital Structure. Journal of Corporate Finance 17, 3344 .

Hubbard, R.G., 1998. Capital-Market Imperfections and Investment. Journal of Economic Literature 36, 193-225.

Jensen, M.C., 1986. Agency Costs of Free Cash Flow, Corporate Finance, and Takeovers. American Economic Review 76, 323-329.

Jensen, M.C., Meckling, W.H., 1976. Theory of the firm: Managerial behavior, agency costs and ownership structure. Journal of Financial Economics 3, 305-360.

Kahle, K.M., Stulz, R.M., 2013. Access to capital, investment, and the financial crisis. Journal of Financial Economics 110, 280-299.

Kaplan, S.N., Zingales, L., 1997. Do Investment-Cash Flow Sensitivities Provide Useful Measures of Financing Constraints? The Quarterly Journal of Economics 112, 169-215. arXiv:arXiv:1011.1669v3.

Korajczyk, R.a., Levy, A., 2003. Capital Structure Choice: Macroeconomic Conditions and Financial Constraints. Journal of Financial Economics 68, 75-109.

Krivogorsky, V., Joh, G.H., DeBoskey, D., 2018. The influence of supply side factors on firm's borrowing decisions: European evidence. Global Finance Journal 35, $202-222$.

Lemmon, M., Roberts, M.R., 2010. The Response of Corporate Financing and Investment to Changes in the Supply of Credit. Journal of Financial and Quantitative Analysis 45, 555-587.

Love, I., Zaidi, R., 2010. Trade Credit, Bank Credit and Financial Crisis. International 
Review of Finance 10, 125-147.

Malmendier, U., Tate, G., 2005. CEO Overconfidence and Corporate Investment. The Journal of Finance 60, 2661-2700. arXiv:arXiv:1011.1669v3.

McNichols, M.F., Stubben, S.R., 2008. Does Earnings Management Affect Firms' Investment Decisions? The Accounting Review 83, 1571-1603.

Modigliani, F., Miller, M.H., 1958. The Cost of Capital, Corporation Finance and the Theory of Investment. American Economic Review 48, 261-297.

Modigliani, F., Miller, M.H., 1963. Corporate Income Taxes and the Cost of Capital: A Correction. American Economic Review 53, 433-443.

Muradoğlu, Y.G., Onay, C., Phylaktis, K., 2014. European integration and corporate financing. International Review of Financial Analysis 33, 138-157.

Myers, S.C., 1977. Determinants of Corporate Borrowing. Journal of Financial Economics $5,147-175$.

Nivorozhkin, E., 2005. Financing choices of firms in EU accession countries. Emerging Markets Review 6, 138-169.

Ohlson, J.A., 1980. Financial Ratios and the Probabilistic Prediction of Bankruptcy. Journal of Accounting Research 18, 109-131.

Opler, T.C., Titman, S., 1994. Financial distress and corporate performance. The Journal of Finance 49, 1015-1040.

Orlova, S.V., Sun, L., 2018. Institutional determinants of cash holdings speed of adjustment. Global Finance Journal 37, 123-137.

Öztekin, Ö., 2015. Capital Structure Decisions around the World: Which Factors Are Reliably Important? Journal of Financial and Quantitative Analysis 50, 301-323.

Öztekin, Ö., Flannery, M.J., 2012. Institutional Determinants of Capital Structure Adjustment Speeds. Journal of Financial Economics 103, 88-112.

Rajan, R., Zingales, L., 1995. What Do We Know about Capital Structure? Some Evidence from International Data. Journal of Finance 50, 1421-1460.

Ramezani, C.A., Soenen, L., Jung, A., 2002. Growth, Corporate Profitability, and Value Creation. Financial Analysts Journal 58, 56-67.

Stiglitz, J.E., 1969. A re-examination of the Modigliani-Miller theorem. The American Economic Review 59, 784-793. 
Watson, R., Wilson, N., 2002. Small and Medium Size Enterprise Financing: A Note on Some of the Empirical Implications of a Pecking Order. Journal of Business Finance \& Accounting 29, 557-578. 
Table 1. Time and geographical distribution of firms in the sample

\begin{tabular}{lccccccccccccccc}
\hline & $\mathbf{2 0 0 4}$ & $\mathbf{2 0 0 5}$ & $\mathbf{2 0 0 6}$ & $\mathbf{2 0 0 7}$ & $\mathbf{2 0 0 8}$ & $\mathbf{2 0 0 9}$ & $\mathbf{2 0 1 0}$ & $\mathbf{2 0 1 1}$ & $\mathbf{2 0 1 2}$ & $\mathbf{2 0 1 3}$ & $\mathbf{2 0 1 4}$ & $\mathbf{2 0 1 5}$ & $\mathbf{2 0 1 6}$ & $\mathbf{2 0 1 7}$ & Total \\
\hline Bulgaria & 230 & 244 & 245 & 247 & 247 & 247 & 247 & 247 & 246 & 244 & 244 & 243 & 243 & 242 & 3,416 \\
Croatia & 92 & 108 & 108 & 108 & 109 & 109 & 109 & 107 & 104 & 104 & 105 & 103 & 101 & 101 & 1,468 \\
Czech Republic & 43 & 43 & 41 & 41 & 37 & 37 & 38 & 38 & 40 & 39 & 39 & 39 & 38 & 38 & 551 \\
Estonia & 11 & 17 & 18 & 18 & 18 & 18 & 17 & 17 & 17 & 17 & 16 & 16 & 16 & 16 & 232 \\
Hungary & 46 & 41 & 42 & 41 & 40 & 41 & 41 & 40 & 40 & 41 & 37 & 34 & 33 & 34 & 551 \\
Latvia & 1 & 28 & 29 & 29 & 29 & 30 & 29 & 30 & 28 & 29 & 26 & 23 & 23 & 20 & 354 \\
Lithuania & 6 & 23 & 29 & 30 & 30 & 31 & 31 & 29 & 29 & 28 & 26 & 23 & 22 & 22 & 359 \\
Poland & 573 & 575 & 580 & 581 & 581 & 583 & 586 & 589 & 589 & 589 & 594 & 592 & 592 & 590 & 8,194 \\
Romania & 149 & 150 & 151 & 151 & 151 & 151 & 151 & 151 & 151 & 151 & 151 & 150 & 150 & 150 & 2,108 \\
Slovakia & 41 & 40 & 40 & 40 & 40 & 40 & 40 & 40 & 40 & 40 & 40 & 40 & 40 & 40 & 561 \\
Slovenia & 53 & 53 & 53 & 53 & 53 & 53 & 53 & 53 & 53 & 53 & 53 & 53 & 53 & 53 & 742 \\
\hline Total & 1,245 & 1,322 & 1,336 & 1,339 & 1,335 & 1,340 & 1,342 & 1,341 & 1,337 & 1,335 & 1,331 & 1,316 & 1,311 & 1,306 & 18,536 \\
\hline
\end{tabular}


Table 2. Capital expenditure and capital structure

Estimates of Equation (1) by means of a panel system-GMM estimator. Robust standard errors are reported in parenthesis. The signs ***,**, and * indicate statistical significance at the $1 \%, 5 \%$, and $10 \%$, respectively.

\begin{tabular}{|c|c|c|c|}
\hline & Full sample (2004-2017) & $G F C(2008-2010)$ & $E D C(2011-2014)$ \\
\hline \multirow{2}{*}{ Capex $_{\mathrm{t}-1}$} & $0.2594^{* * *}$ & $0.1945^{* * *}$ & $0.2558^{* * *}$ \\
\hline & $(0.000)$ & $(0.010)$ & $(0.006)$ \\
\hline \multirow[t]{2}{*}{ Excess debt $t_{t-1} * N^{2} D_{t-1}$} & 0.0120 & 0.0203 & 0.0250 \\
\hline & $(0.008)$ & $(0.015)$ & $(0.016)$ \\
\hline \multirow{2}{*}{ Excess debt ${ }_{\mathrm{t}-1} * \mathrm{ED}_{\mathrm{t}-1}$} & $-0.0269 * * *$ & $-0.0277^{* * *}$ & $-0.0575^{* * *}$ \\
\hline & $(0.000)$ & $(0.011)$ & $(0.008)$ \\
\hline \multirow[t]{2}{*}{ Profit $_{t-1}$} & $0.0348^{* * *}$ & $0.0242^{* * *}$ & $0.0282^{* * *}$ \\
\hline & $(0.000)$ & $(0.005)$ & $(0.003)$ \\
\hline \multirow[t]{2}{*}{ Size $_{t-1}$} & $-0.0007^{* * *}$ & $0.0015^{*}$ & -0.0007 \\
\hline & $(0.000)$ & $(0.001)$ & $(0.000)$ \\
\hline \multirow[t]{2}{*}{ Tangible $_{\mathrm{t}-1}$} & $-0.0011^{* * *}$ & $0.0296^{* * *}$ & $-0.0107^{* * *}$ \\
\hline & $(0.000)$ & $(0.008)$ & $(0.003)$ \\
\hline \multirow[t]{2}{*}{ Intangible $_{\mathrm{t}-1}$} & $0.0187 * * *$ & $0.2278^{* * *}$ & -0.0037 \\
\hline & $(0.000)$ & $(0.020)$ & $(0.011)$ \\
\hline \multirow[t]{2}{*}{ Growth $_{\mathrm{t}-1}$} & $0.0092^{* * *}$ & $0.0122^{* * *}$ & $0.0069^{* * *}$ \\
\hline & $(0.000)$ & $(0.000)$ & $(0.000)$ \\
\hline \multirow[t]{2}{*}{$\mathrm{WC}_{\mathrm{t}-1}$} & $0.0363^{* * *}$ & $0.0416^{* * *}$ & $0.0220 * * *$ \\
\hline & $(0.000)$ & $(0.007)$ & $(0.004)$ \\
\hline \multirow[t]{2}{*}{ Ohlson $_{\mathrm{t}-1}$} & $-0.0013^{* * *}$ & $-0.0003^{* *}$ & $-0.0010^{* * *}$ \\
\hline & $(0.000)$ & $(0.000)$ & $(0.000)$ \\
\hline \multirow[t]{2}{*}{ Cash $_{\mathrm{t}-1}$} & $0.0572^{* * *}$ & $0.0911^{* * *}$ & $0.0516 * * *$ \\
\hline & $(0.000)$ & $(0.009)$ & $(0.005)$ \\
\hline \multirow[t]{2}{*}{ Eurot $_{t}$} & $0.0032^{* * *}$ & 0.0059 & $0.0071^{* * *}$ \\
\hline & $(0.000)$ & $(0.008)$ & $(0.003)$ \\
\hline \multirow[t]{2}{*}{ Intercept } & $0.0148^{* * *}$ & $-0.0283^{* * *}$ & $0.0244^{* * *}$ \\
\hline & $(0.000)$ & $(0.011)$ & $(0.005)$ \\
\hline
\end{tabular}




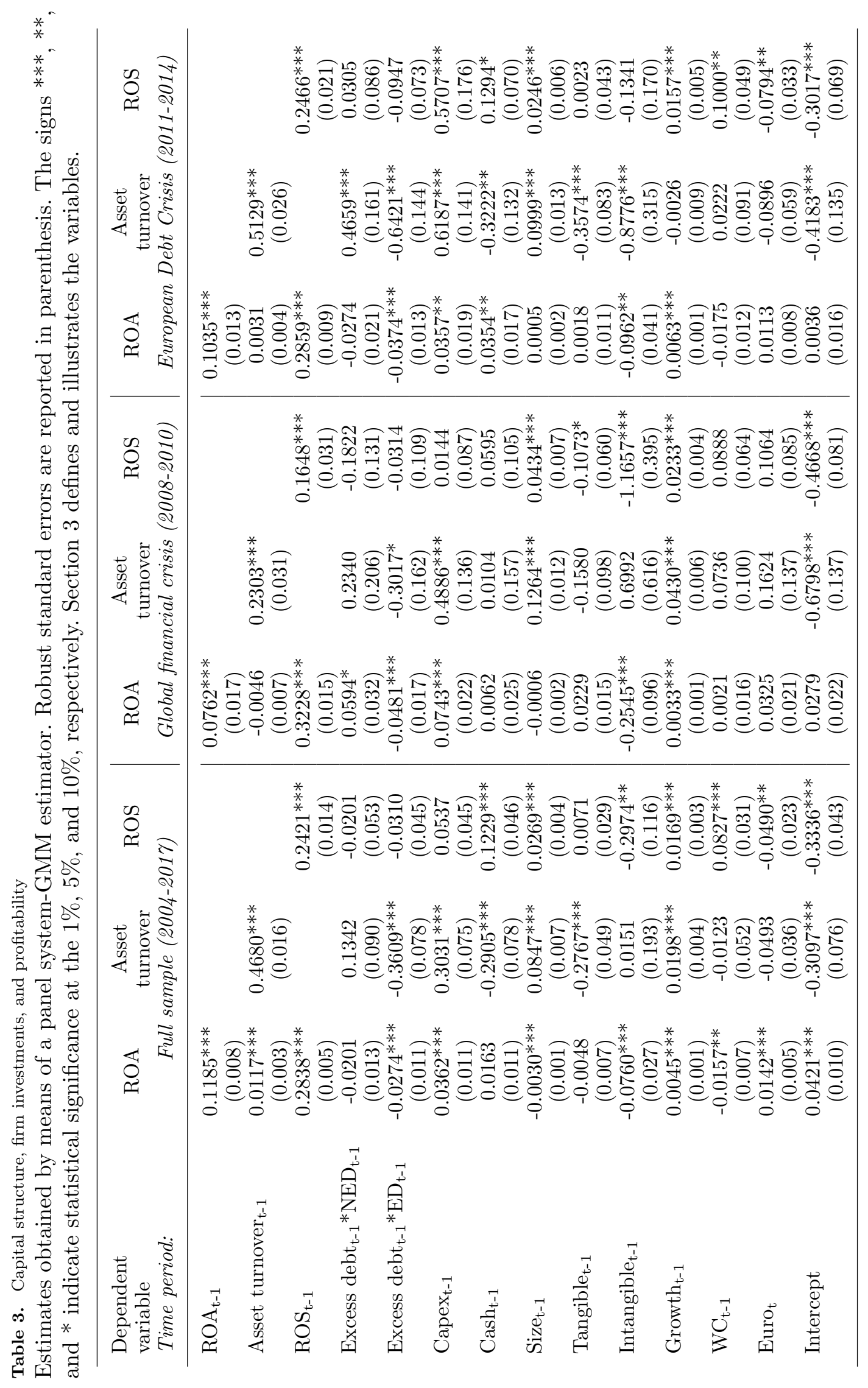


Table 4. Pre-crisis leverage and overall performance

Columns (1) and (2) report the results for ordinary least squares regressions with ROA, cumulated over the 2008-2017 period, as dependent variable. ROS and Asset turnover are both cumulated over the same time period. Excess debt and Ohlson are both measured at the end of 2007, before the beginning of the GFC. Columns (3) and (4) report the results of interquartile regressions, again with the cumulated ROA as dependent variable, comparing the $80^{\text {th }}$ with the $20^{\text {th }}$ percentile. All regressions include industry effects. Standard errors are reported in parenthesis. Statistical significance at the $1 \%, 5 \%$, and $10 \%$ is marked with $* * *, * *$, and $*$, respectively.

\begin{tabular}{lcccc}
\hline & $(1)$ & $(2)$ & $(3)$ & $(4)$ \\
\hline ROS (cum.) & $0.3554^{* * *}$ & $0.3221^{* * *}$ & 0.0210 & -0.0046 \\
& $(0.019)$ & $(0.033)$ & $(0.052)$ & $(0.039)$ \\
Asset turnover (cum.) & $0.0271^{* * *}$ & $0.0281^{* * *}$ & $0.0263^{* * *}$ & $0.0205^{* *}$ \\
& $(0.004)$ & $(0.005)$ & $(0.006)$ & $(0.008)$ \\
Excess debt*ED & 0.0890 & $-0.3889^{* *}$ & -0.0154 & 0.3056 \\
& $(0.236)$ & $(0.192)$ & $(0.214)$ & $(0.291)$ \\
Excess debt*NED & $-1.1420^{* * *}$ & $-0.7255^{*}$ & $-0.9541^{*}$ & $-1.2154^{*}$ \\
& $(0.391)$ & $(0.415)$ & $(0.541)$ & $(0.676)$ \\
Ohlson & & $-0.0654^{* * *}$ & & -0.0078 \\
& & $(0.015)$ & & $(0.026)$ \\
Constant & -0.0614 & $-0.3526^{* * *}$ & $0.1294^{*}$ & -0.0523 \\
& $(0.058)$ & $(0.089)$ & $(0.072)$ & $(0.321)$ \\
\hline
\end{tabular}




\section{Appendix A: Determinants of the optimal debt ratio}

\section{Analysis of capital structure: methodology}

This appendix provides a thorough description of our analysis of firms' capital structure decisions. In particular, our objective consists in identifying whether firms are over or under-levered compared to their optimal level of leverage. To do so, we rely on a classic model of optimal capital structure as defined in Equation A.1):

$$
\frac{D_{i, t}}{A_{i, t}}=\alpha+\beta X_{i, t-1}+u_{i}+\epsilon_{i, t}
$$

where $D$ is total financial debt, $A$ is total assets, $X$ is a vector of firm characteristics, $i$ indicates firm, $t$ indicates time, $u_{i}$ indicates firm fixed effects, $\alpha$ and $\beta$ are parameters, and $\epsilon$ is the error term.

Then, for any year in the sample we define firms as over-levered (under-levered) if the debt ratio at the end of the year is greater (smaller) than the estimated target leverage for that corresponding year, and define the debt misalignment (excess debt, $E D)$ accordingly as in Equation A.2):

$$
E D_{i, t}=\frac{D_{i, t}}{A_{i, t}}-\left(\frac{D_{i, t}}{A_{i, t}}\right)^{*}
$$

where $\left(\frac{D_{i, t}}{A_{i, t}}\right)^{*}$ indicates target leverage for firm $i$ at time $t$.

More precisely, for each year in the sample period we estimate excessive debt by first running rolling regressions of Equation (A.1) using only past information in order to avoid the so-called look-ahead bias9. Then, we use year-specific targets to estimate the deviation of the observed capital structure from the estimated optimal level.

As potential determinants of target leverage, we consider the firm-level characteristics typically considered in the pertinent literature. A consolidated result in previous works is the negative relationship of debt ratios with profitability and growth opportunities, and the positive relationship of leverage with firm size and tangible assets (see,

${ }^{9}$ See Hovakimian and Li 2011) for a thorough description of the estimation procedure and the potential consequences of failing to account for the look-ahead bias. 
among others, Rajan and Zingales (1995) and Frank and Goyal (2009)). Therefore, we include the following variables: profitability, defined as the ratio between operating cash flow and total assets; size, measured as the natural logarithm of firm sales, corrected for inflation 10 tangible, defined as the ratio of fixed assets to total assets; growth opportunities (growth), measured as the ratio between the total market capitalization and the book value of equity. Al-Najjar (2011) shows how the same set of potential determinants of leverage used for developed markets can validly be adopted also for emerging economies. As discussed in the literature review, firms may attribute value to financial flexibility, so they may decide to increase leverage to accumulate liquid resources to be used for quickly undertaking new projects; for this reason, we include the cash ratio (cash), defined as the sum of cash and equivalents divided by total assets. Given the growing importance of intangible assets in the modern economy, we include the variable intangible, obtained as the ratio between intangible assets to total assets. In recent years the market for intangibles has grown sensibly, and their use in securitization contracts has increased remarkably (Graham et al. (2018)); hence, we expect them to behave similarly to tangible assets in providing a form of collateral that may be used to increase a firm's debt capacity. We therefore expect a positive relationship between intangibles and debt. We also control for the relative length of the cash cycle on capital structure, by including the net working capital ratio $(W C)$. We expect a positive relationship between working capital and financial leverage, as the two may act as partial substitutes in funding firms' operations. We then include the average debt ratio in the industry in which the firm operates (industry) in order to account for differences in capital structure that are connected with industry, rather than firm, characteristics. Finally, we introduce the dummy Euro, which is equal to one if the company is incorporated in a country that adopts the European common currency in the corresponding year, to account for potential effects of belonging to the Euro area.

We then analyze capital structure decisions under a different perspective, by examining the relationship between asset growth and sources of funds. To this end, we estimate the model proposed by Watson and Wilson (2002), defined by the following

${ }^{10}$ We deflate nominal values using 2010 as the base year. 
Equation:

$$
\frac{\Delta A_{i, t}}{A_{i, t-1}}=\alpha+\beta_{1} \frac{R E_{i, t}}{A_{i, t-1}}+\beta_{2} \frac{\Delta D_{i, t}}{A_{i, t-1}}+\beta_{3} \frac{\Delta E_{i, t}}{A_{i, t-1}}+\beta_{4} \frac{\Delta W C_{i, t}}{A_{i, t-1}}+u_{i}+\epsilon_{i, t}
$$

where $i$ indicates firm, $t$ indicates time, $\Delta A$ indicates the change in total assets, $R E$ is retained earnings, $\Delta D$ is the change in financial debt, $\Delta E$ is the change in equity (net of reinvested earnings), $\Delta W C$ is the change in working capital, $u$ indicates firm fixed effects, and $\epsilon$ is the error term. This model focuses on how the growth in assets is funded, by showing how changes in each type of financing sources impacts upon total financing. Equation A.3 is generally used as a way to test for the validity of the pecking order theory: if the magnitude of the coefficients produces a hierarchy that is consistent with the ordering prescribed by the theory, then it is seen as an empirical validation of the theory itself. While the relative merit of alternative theories of capital structure is not the main focus of our work, the relationship between asset growth and alternative funding sources can help us in interpreting the results from the analysis of the relationship between capital structure and profitability. Indeed, if firms have a long term capital structure target, but their year-by-year behaviour is strongly affected by pecking order arguments, as the empirical literature on capital structure suggests, then we should expect to observe that their asset growth is mainly funded through retained earnings and financial debt. In light of the fact that the GFC and the EDC reduced both profitability and the availability of equity capital (Kahle and Stulz $(2013))$, then if the debt overhang hypothesis holds we should expect firms with little internal funds and limited residual debt capacity to reduce investments and experience a decline in performance.

\section{Analysis of capital structure: results}

We begin our analysis by estimating the optimal debt ratio as a function of a set of firm characteristics. Table A.1 reports our findings for the estimation of Equation A.1) using data referring to the entire sample period.

[Table A.1 about here.] 
Column (1) only considers the four most commonly used determinants of leverage, as in Rajan and Zingales (1995). In line with previous literature, we find that more profitable firms are less indebted, those with an higher proportion of tangible assets use more debt, and larger firms tend to have an higher leverage. We then find that growth opportunities are associated with an higher debt ratio, contrasting with older results in the literature (see, e.g. Rajan and Zingales (1995), Flannery and Rangan (2006), and Öztekin (2015)), but consistent with Elsas and Florysiak (2011). This is also consistent with firms relying more on debt to support growth, in a period of recession where internal funds may have become insufficient: this would result in higher debt for firms which have higher growth opportunities and, consequently, higher investments to pursue them. All these results consistently hold in augmented specifications of Equation (A.1), with the exception of firm size that results not statistically significant for the models in columns (2), (3) and (4). In Column (2) we include two additional variables: the annual average debt ratio of the industry in which a firm operates, that always have a significant and positive coefficient, and the proportion of intangible assets to total assets, that also has a significant and positive relationship with leverage. While this latter result may appear contradictory, given that intangible assets have sometimes been used as proxies for the costs of bankruptcy, so that they had a negative relationship with leverage, it should instead be seen as a finding consistent with the evolution of the modern economy. Indeed, the market for intangibles has grown significantly in the last decade, as documented in particular by Graham et al. (2018) for the US market, so that these assets may become a form of implicit collateral for debtholders, similarly to tangible assets. This would in turn imply that, by providing collateral value to creditors, they enhance the debt capacity of firms, and this results in a positive regression coefficient.

We then further enrich our model by adding a dummy equal to one if the firm is incorporated in a country that adopts the Euro as a currency (Euro), but it does not result statistically significant (Column (3)). In Columns (4) and (5) we include time fixed effects, in order to incorporate the effects of macroeconomic shocks in the model, as these are likely to affect firms' financing decisions (Krivogorsky et al. (2018)). We also interact the time fixed effects with the Euro area dummy, in order to allow for 
differences in the effect of these shocks between countries that adopt and do not adopt the Euro, given that a significant part of the sample period refers to a financial crisis that is deeply connected with the architecture of the European common currency 11 . Our results indicate that firms in Euro-area countries were on average more indebted before the crisis, as suggested by the interaction between Euro and the dummy for the year 2008. On the contrary, they ended up being less indebted after the crisis, and this difference increases as we approach the end of the sample period, as highlighted by the interaction between the dummy Euro and those for the years 2015, 2016 and 2017. In Column (5) we also add two additional firm-level regressors that are likely to affect firms' financing decisions. One is the cash ratio (cash), and we find that firms with higher liquidity on their balance sheet have less debt, indicating that firms were likely not issuing debt to pile up cash reserves, but on the contrary these are likely to be the result of the accumulation of internally generated cash flows. The second is the working capital ratio $(W C)$, for which we also find a negative effect on leverage. This indicates that trade credit was not used as a replacement for financial debt, but as a complement ${ }^{12}$, firms in need of more external capital relied on both financial debt and trade credit; firms that instead were able to support their activity with internal funds, or those that made equity issues, so that they reported a lower financial debt, used their internal cash flow or proceeds from equity issues to repay their debts to both financial and trade creditors. This finding lends no support to the substitution hypothesis between bank and trade credit in times of financial crises, and suggests instead that liquidity shocks may propagate along the supply chain, as also reported by Love and Zaidi (2010). In order to better investigate this finding, we repeat the regression on two different sub-periods: before the GFC (using data until 2008), and after the beginning of the GFC (using data after 2008). These additional results are reported in Table A.2, with Column (1) referring to the pre-crisis and Column (2) to the post-crisis period. It is interesting to note how, before the GFC, we find evidence

${ }^{11}$ Note that, in order to preserve space and for an easier readability of Table A.1 we only report the coefficients for the statistically significant interactions between time fixed effects and the dummy Euro.

${ }^{12}$ Recall that a more positive $W C$ indicates lower net operating liabilities, and vice-versa. The negative coefficient therefore indicates that higher operating liabilities (i.e. a lower $W C$ ) were associated with higher financial debt. 
of substitution between trade credit and financial debt, as indicated by the positive coefficient for $W C$. On the contrary, after the explosion of the GFC this relationship reverses, and trade credit appears not to be a substitute for financial debt, suggesting that firms that were not able to raise capital from banks were also having difficulties in obtaining credit from their suppliers.

[Table A.2 about here.]

It is also interesting to notice the increase (in absolute value) of the coefficients for profit and cash following the GFC, suggesting that changing market conditions have likely induced firms to adopt a behavior more consistent with the pecking order theory, so that firms with larger internal funds avoided raising new external capital and relied less on debt. This is consistent with the idea that both the GFC and the EDC have increased the cost of raising new capital, so that firms may have rationally decided to avoid accessing capital markets when they had sufficient internal funds.

We conclude this part of the analysis by examining the relationship between asset growth and financing decisions; to this end, we estimate the Watson and Wilson (2002) model from Equation A.3. We report the corresponding results in Table A.3.

[Table A.3 about here.]

When looking at the full sample period, our findings indicate that the relative importance of the different funding instruments is perfectly consistent with the pecking order theory: retained earnings have the largest coefficient, followed by debt and equity, while working capital management represents a marginal source of funds. This is true for firms incorporated both in the Euro area and outside it. However, Euro area firms seem to rely less on internal funds, more on debt and less on equity than firms based in countries not adopting the common currency, consistently with the findings of Muradoğlu et al. (2014).

When separating the pre-crisis period (2004-2008) from the crisis period (20092014), interesting patterns emerge. When looking at firms based in the Euro area, we find that before the crisis they relied on internal funds and equity as the two primary sources of capital, while debt came in third place. On the contrary, during the crisis their use of external equity decreased, at the advantage of debt, which becomes the 
second source of funds, coming after reinvested earnings. Moreover, during the crisis working capital is not even statistically significant, confirming our previous finding that, during the GFC and the EDC, there was no substitution effect between financial debt and trade credit. When looking instead at firms based outside the Euro area, we still observe a decrease in the use of new external equity during the crisis, but the difference between the two periods is much less pronounced. Again, these findings are in line with those reported in Muradoğlu et al. (2014): when their country of incorporation joins the European Union, companies increase the use of external equity. Then, when they also adopt the European common currency, they experience an increase in debt capacity, and gradually increase their use of leverage. 
Table A.1. Determinants of debt ratios

Estimates of Equation (A.1) by means of a panel fixed-effects estimator. Robust standard errors are reported in parenthesis. The signs ***,**, and * indicate statistical significance at the $1 \%, 5 \%$, and $10 \%$, respectively.

\begin{tabular}{|c|c|c|c|c|c|}
\hline & (1) & $(2)$ & (3) & (4) & (5) \\
\hline Profitability & $\begin{array}{c}-0.1684^{* * *} \\
(0.031)\end{array}$ & $\begin{array}{c}-0.1571^{* * *} \\
(0.029)\end{array}$ & $\begin{array}{c}-0.1571^{* * *} \\
(0.029)\end{array}$ & $\begin{array}{c}-0.1581^{* * *} \\
(0.029)\end{array}$ & $\begin{array}{c}-0.1558^{* * *} \\
(0.028)\end{array}$ \\
\hline Growth & $\begin{array}{c}0.0080^{* * *} \\
(0.003)\end{array}$ & $\begin{array}{c}0.0131^{* * *} \\
(0.002)\end{array}$ & $\begin{array}{c}0.0131^{* * *} \\
(0.002)\end{array}$ & $\begin{array}{c}0.0153^{* * *} \\
(0.003)\end{array}$ & $\begin{array}{c}0.0159 * * * \\
(0.003)\end{array}$ \\
\hline Tangible & $\begin{array}{c}0.0934^{* * *} \\
(0.029)\end{array}$ & $\begin{array}{c}0.0911^{* * *} \\
(0.025)\end{array}$ & $\begin{array}{c}0.0921^{* * *} \\
(0.025)\end{array}$ & $\begin{array}{c}0.0979^{* * *} \\
(0.025)\end{array}$ & $\begin{array}{c}0.0592^{* *} \\
(0.024)\end{array}$ \\
\hline Size & $\begin{array}{c}0.0099^{* *} \\
(0.005)\end{array}$ & $\begin{array}{l}0.0071 \\
(0.004)\end{array}$ & $\begin{array}{c}0.0071 \\
(0.004)\end{array}$ & $\begin{array}{c}0.0058 \\
(0.005)\end{array}$ & $\begin{array}{c}0.0102^{* *} \\
(0.004)\end{array}$ \\
\hline Intangible & & $\begin{array}{c}0.2726^{* * *} \\
(0.099)\end{array}$ & $\begin{array}{c}0.2730^{* * *} \\
(0.099)\end{array}$ & $\begin{array}{c}0.2512^{* *} \\
(0.099)\end{array}$ & $\begin{array}{c}0.1809^{*} \\
(0.100)\end{array}$ \\
\hline Cash & & & & & $\begin{array}{c}-0.2512^{* * *} \\
(0.038)\end{array}$ \\
\hline $\mathrm{WC}$ & & & & & $\begin{array}{c}-0.1193^{* * *} \\
(0.033)\end{array}$ \\
\hline Industry & & $\begin{array}{c}0.7099^{* * *} \\
(0.052)\end{array}$ & $\begin{array}{c}0.7133^{* * *} \\
(0.052)\end{array}$ & $\begin{array}{c}0.6698^{* * *} \\
(0.057)\end{array}$ & $\begin{array}{c}0.6410^{* * * *} \\
(0.055)\end{array}$ \\
\hline Euro & & & $\begin{array}{c}-0.0189 \\
(0.014)\end{array}$ & & \\
\hline Euro*2008 & & & & $\begin{array}{c}0.0613^{* * *} \\
(0.022)\end{array}$ & $\begin{array}{c}0.0594^{* * *} \\
(0.022)\end{array}$ \\
\hline Euro*2015 & & & & $\begin{array}{c}-0.0316^{*} \\
(0.017)\end{array}$ & $\begin{array}{c}-0.0299^{*} \\
(0.016)\end{array}$ \\
\hline Euro*2016 & & & & $\begin{array}{c}-0.0459^{* *} \\
(0.020)\end{array}$ & $\begin{array}{c}-0.0415^{* *} \\
(0.020)\end{array}$ \\
\hline Euro*2017 & & & & $\begin{array}{c}-0.0702^{* * *} \\
(0.019)\end{array}$ & $\begin{array}{c}-0.0634^{* * *} \\
(0.019)\end{array}$ \\
\hline Intercept & $\begin{array}{l}0.0448 \\
(0.054)\end{array}$ & $\begin{array}{c}-0.0926^{*} \\
(0.051)\end{array}$ & $\begin{array}{c}-0.0917^{*} \\
(0.051)\end{array}$ & $\begin{array}{c}-0.0900^{*} \\
(0.051)\end{array}$ & $\begin{array}{r}-0.0731 \\
(0.051)\end{array}$ \\
\hline Firm fixed effects & Yes & Yes & Yes & Yes & Yes \\
\hline Year fixed effects & No & No & No & Yes & Yes \\
\hline
\end{tabular}


Table A.2. Financial debt and working capital before and after the global financial crisis Estimates of Equation A.1 by means of a panel fixed-effects estimator on two subsamples of the dataset. Robust standard errors are reported in parenthesis. The signs $* * *, * *$, and $*$ indicate statistical significance respectively at the $1 \%, 5 \%$, and $10 \%$.

\begin{tabular}{lcc}
\hline & $(1)$ & $(2)$ \\
\hline \multirow{2}{*}{ Profitability } & $-0.0561^{* *}$ & $-0.1577^{* * *}$ \\
& $(0.029)$ & $(0.034)$ \\
Growth & 0.0055 & $0.0188^{* * *}$ \\
& $(0.004)$ & $(0.004)$ \\
Tangible & $0.0713^{* * *}$ & $0.0610^{* *}$ \\
& $(0.023)$ & $(0.030)$ \\
Size & 0.0060 & 0.0078 \\
& $(0.008)$ & $(0.005)$ \\
Intangible & $0.1471^{*}$ & $0.1934^{* * *}$ \\
& $(0.083)$ & $(0.037)$ \\
Cash & $-0.0735^{* * *}$ & $-0.2442^{* * *}$ \\
& $(0.027)$ & $(0.048)$ \\
WC & $0.2508^{* * *}$ & $-0.1651^{* * *}$ \\
& $(0.085)$ & $(0.039)$ \\
Intercept & -0.0880 & -0.0338 \\
& $(0.093)$ & $(0.063)$ \\
\hline
\end{tabular}




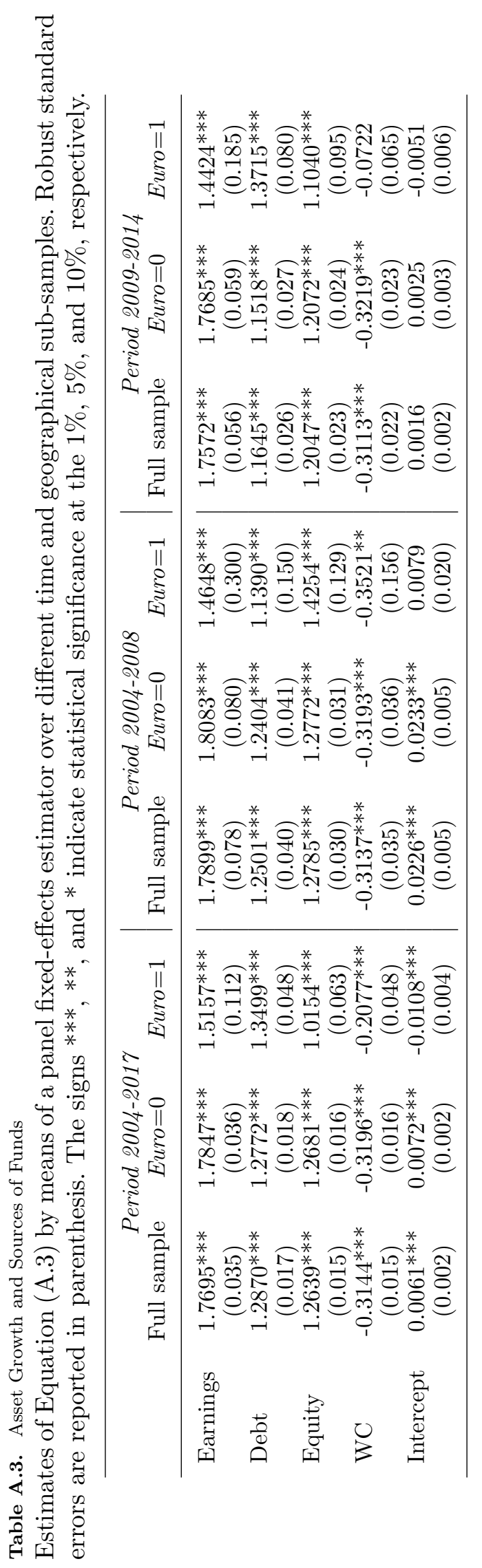

